\title{
Heavy Metal Contamination of Medicinal Plants and Potential Implications on Human Health
}

\author{
DANA-MIHAELA ASIMINICESEI ${ }^{1}$, IONELA CATALINA VASILACHI', \\ MARIA GAVRILESCU ${ }^{1,2 *}$ \\ ${ }^{1}$ Gheorghe Asachi Technical University of Iasi, Cristofor Simionescu Faculty of Chemical Engineering and Environmental \\ Protection, Department of Environmental Engineering and Management, 73 Prof. Dimitrie Mangeron Blvd., 700050, Iasi, \\ Romania \\ ${ }^{2}$ Academy of Romanian Scientists, 3 Ilfov Str., 50044, Bucharest, Romania
}

\begin{abstract}
This survey focuses on the problem of medicinal plants contamination due to environmental pollution produced by many different industrial activities and atmospheric deposition of some toxic compounds. This analysis is important since plants can easily absorb organic and inorganic compounds from all environmental compartments (water, soil, air), which can enter and be transferred in the trophic chain, up to humans. Medicinal plants are relevant for study in relation with their interactions with different contaminants, in particular those inorganic persistent as heavy metals, because they are used in entire world for their beneficial properties, and represent a significant part of traditional medicine. According to World Health Organization (WHO), 65-80\% of world's population depends on herbal products as the primary form of health care. Frequent use of medicinal plants to improve health, in the context of current pollution, requires special attention, since they can contain heavy metals in their structures, which can generate hazards and risks on human health throughout the subsequent consumption of contaminated medicinal plants as teas, other drinks, cosmetics.
\end{abstract}

Keywords: bioaccumulation, contamination, health risk, heavy metals, medicinal plants

\section{Introduction}

The decrease of environment quality caused by pollution is a consequence of many different human activities. Pollution generates unwanted changes in the environment, with harmful consequences on plants, animals and humans. The nature and concentration of pollutants determine the severity of the environmental impact and harmful effects on human health.

Persistent pollutants - a distinct category of environmental pollutants of organic or inorganic nature possess some specific characteristics, manifested as: harmfulness (toxicity to ecosystems and humans); persistence (can remain for longtime in the environment, being non- or low- biodegradable); bioaccumulation (are absorbed in the fatty tissue of living organisms including humans where bioaccumulate and also are transferred in the food chain, where can be found in higher concentrations); capacity to be transported on long-range distances (due to their persistence, these pollutants are transported over long distances by air and water so that they can be found in areas where they have never been used and, in some cases, they are found around the globe) [1-3]. Due to their toxicity, these pollutants are also named persistent toxic substances (PTS).

Persistent organic pollutants (POPs) are toxic substances represented by carbon-based organic compounds and chemical mixtures. Among the first and best known POPs are industrial chemicals such as PCBs and pesticides such as DDT (dichlorodiphenyltrichloroethane). POPs are usually industrially produced and by-products, of relatively recent date, whose production intensified after World War II. In order to limit the effects of persistent organic pollutants on the environment and human health, the Stockholm Convention, adopted in May 2001 under the United Nations Environment Program (UNEP) (and entered into force in 2004), provided a series of measures to

*email:mgav@tuiasi.ro 
reduce and eliminate production, use and release of these substances [4]. In 2002, the Convention covered 12 POPs considered to have the greatest impact, the so-called "dirty dose". Other substances with the same characteristics were then added to the treaty.

Persistent inorganic pollutants (PIPs) is another category of persistent pollutants which, similar to POPs, are able to generate serious impacts and risks at a global scale, not only to the environmental components (water, air, soil), but also to human health [5-7]. Some inorganic chemicals which are not classified as persistent may transform into PIPs, depending on their physico-chemical properties as well as environmental influences [8]. Generally, PIPs includes pesticides as silicate, borate, sulfur derivatives extracted from mines and then transformed in powders, with poisoning properties or able to physically interfere with pest. Some of these pesticides which contain metals such as: arsenic, cooper, lead, tin salts, are highly toxic. As persistent inorganic pollutants, heavy metals are non-biodegradable, can accumulate in soils and biological compartments and move through the food chain, then affecting the normal functions of the human body $[9,10]$.

Therefore, both POPs and PIPs can generate considerable impacts and risks for ecological systems and humans. A great part of the literature dedicated to different pollutants belonging to these two categories addresses the threats associated with the presence of heavy metals in the environment.

Heavy metals are significant environmental pollutants, and their toxicity significantly affects ecological, evolutionary, nutritional and environmental systems. The sources of contamination of medicinal plants with heavy metals are the long-term irrigated areas with treated or untreated wastewater, those with heavy car traffic or tailings dumps, or other types of waste deposits that may contain metals. Soils in various parts of the world are slightly to moderately contaminated with toxic heavy metals such as $\mathrm{Cd}, \mathrm{Cu}, \mathrm{Zn}, \mathrm{Ni}, \mathrm{Co}, \mathrm{Cr}, \mathrm{Pb}$ and $\mathrm{As}$, as a consequence of long-term use of phosphate fertilizers, soil amendment with sludge from wastewater treatment plants, traffic, the presence of industrial waste, inadequate irrigation practices [11, 12]. Heavy metals, as persistent toxic substances, can also generate massive pollution of soils and waters, the most common toxic metals being lead $(\mathrm{Pb})$, chromium $(\mathrm{Cr})$, arsenic $(\mathrm{As})$, zinc $(\mathrm{Zn})$, cadmium $(\mathrm{Cd})$, copper $(\mathrm{Cu})$, mercury $(\mathrm{Hg})$ and nickel (Ni). Most metals cannot be degraded by microbial or chemical action, so they can persist in soils long after their introduction. Toxic metals in the soil can severely inhibit the biodegradation processes of some organic pollutants $[13,14]$.

Plants constantly interact with soils polluted with heavy metals and, being immobile organisms, have developed complex defense strategies, which involve an enormous variety of chemical metabolites as tools to overcome stress conditions. Studies proved that the metals present in the soil solution as a soluble component or solubilized by exudates from plant roots are thus bioavailable for absorption by plants. Although plants need a number of metals for growth, development and maintenance, they can become toxic if they are in excessive amounts, but the ability of plants to accumulate essential metals makes it possible to absorb other metals, whose presence affects the plant $[12,15,16]$. Some plants can tolerate high amount of heavy metals, being cultivated to extract them and clean the soil by phytoremediation. However, the majority of plants cultivated on contaminated soils are agricultural crops, industrial plants or other beneficial vegetables which are intended to human consumption and use. Therefore, human health can be severely affected by the consumption of vegetables and fruits from plants growing in soils containing high concentrations of heavy metals. For example, some studies estimate that about half of the lead in the human body comes from food, which in a proportion of approximately $50 \%$ originate from plants $[17,18]$.

Specialized literature and daily practice demonstrate that some plants have been and continue to be widely used both in the pharmaceutical industry and in the treatment of diseases through so-called ethno-medicine, consumers revealing a growing interest in these products. Phytomedicine exploits many active principles produced by plants as metabolites. Unfortunately, the quality and quantity of these active principles in plants are influenced by a multitude of factors, of which the most important are related to environmental pollutants $[19,20]$. The effects of heavy metals toxicity on medicinal plants used in traditional medicines has been reported worldwide, since the accumulation of heavy 
metals in medicinal plants require careful analyses to avoid noticeable metal concentrations reaching the consumer [21-25].

In this context, the goal of our paper is to appraise how the soil pollution with heavy metals can affect the medicinal plants, and how the consumption and use of these plants can affect the human health. So, we reviewed the ways of contamination with heavy metals, the changes produced in plant tissues and highlighted the most frequently affected parts of medicinal plants by heavy metals. Also, we discussed the potential hazards and risk to human health as a consequence of raw herbs consumption and use of commercially available products from herbs.

\section{Therapeutic properties and uses of medicinal plants}

Many plant species are used by humans for their beneficial properties as an important part of traditional medicine and also as significant sources of natural nutrients and antioxidants [26]. Medicinal plants have lower costs than synthetic drugs and they are applied in the treatment of diseases worldwide, e.g. for the prevention and treatment of some chronic diseases: cardiovascular diseases, inflammatory diseases, arthritis, diabetes and others [27]. Medicinal plants have the capacity to produce secondary metabolites as alkaloids, terpenoids and phenolic compounds, with important biological effects such as anti-inflammatory, anticancer and antioxidant properties [28]. Currently, it is about integrated medicine, which involves a lot of plants and their active components, both for the treatment of some diseases and for aromatherapy, primary medicines and several other therapies. They are adopted both at home and in the hospital, for treatments and prevention. Medicinal and aromatic plants represent a continuous hope for human life [29, 30]. The World Health Organization (WHO) estimates that $65-80 \%$ of world's population depends on herbal products as the primary form of health care [31].

Medicinal plants are used in all traditional medicinal systems that have integrated phytotherapy into their doctrines such as Ayurveda, Chinese, Tibetan, Amazonian, African and Unani. There are several ways in which herbs can be prepared to benefit from their antioxidant properties, and some of them are represented by infusion, decoction, maceration and cataplasm.

Numerous studies have shown the beneficial effect of herbs for different health conditions, some of them are presented in Table 1. For example, a study by Zuo et al. [32], showed that the use of Malva sylvestris $L$. has cardioprotective effect and reduces oxidative stress and inflammatory response. Ranjbar et al. [33] showed in a study that a combination of Melissa officinalis L. and Nepeta menthoides Boiss \& Buhse can combat insomnia, depression and anxiety. Another interesting study by Sarma et al. [30] shows that Salix migra inhibited oxidative stress in rats with collagen-induced arthritis, and Ghanbari et al. [34] have shown that spirulina (Spirulina plathensis), improved the memory deficit induced by thetoxic alkaloid (scopolamine) by inhibiting oxidative stress.

Medicinal plants are important sources of natural antioxidants and they are used worldwide as an alternative treatment source for various conditions. These or herbal extracts have been used over time to prevent or even stop disease [35, 31]. Antioxidants are used to support human health and are considered biochemical compounds that have the ability to repel free radicals and reactive oxygen species that are known to be harmful to health. Consumption of antioxidants can reduce the symptoms of diseases associated with oxidative stress, especially chronic diseases [36]. The literature shows that some medicinal plants contain phenols, phenylethanoids, phenylpropanoids, flavonoids, iridoids, lignans and alkaloids and that these compounds have antioxidant, antimicrobial, anti-inflammatory, hepatoprotective and diuretic properties [37]. Medicinal plants are a remedy for diseases caused by oxidative stress, due to their antioxidant properties. Oxidative stress plays an important role in human health and has been correlated with numerous defects in cognitive function in certain health problems such as, aging, post-traumatic disorders and even Parkinson's disease [48]. 
Table 1. Beneficial effects of medicinal plants

\begin{tabular}{|c|c|c|}
\hline \multicolumn{3}{|c|}{ Medicinal herbs and their therapeutic use } \\
\hline Species & $\begin{array}{c}\text { Therapeutic use } \\
\end{array}$ & References \\
\hline Mentha piperita & Bacterial infections, infectious diseases & [38] \\
\hline Lavanda angustifolia & Reduces anxiety & [39] \\
\hline Juniperus communis & Hepatoprotective, have antioxidant potential & [40] \\
\hline Achillea millefolium & $\begin{array}{l}\text { Decreases annual rate of patients with } \\
\text { multiple sclerosis }\end{array}$ & $\begin{array}{l}{[41]} \\
{[42]}\end{array}$ \\
\hline Hyssopus officinalis & Antifungal, antioxidant properties & [43] \\
\hline \multirow[t]{2}{*}{ Acorus calamus } & Treatment of cardiovascular diseases & [44] \\
\hline & $\begin{array}{l}\text { Antidepressant, reduces menopausal } \\
\text { symptoms and depression in postmenopausal } \\
\text { women }\end{array}$ & [45] \\
\hline Valeriana officinalis $L$. & $\begin{array}{l}\text { Sedative, used in anxious states, muscle } \\
\text { relaxation }\end{array}$ & [46] \\
\hline Melisa officinalis & $\begin{array}{c}\text { Sedative, antibacterial, antiviral, antioxidant } \\
\text { and antifungal } \\
\text { activities }\end{array}$ & [47] \\
\hline
\end{tabular}

Direct damage to biological molecules is caused by oxidative stress (oxidation of DNA, carbohydrates, proteins, lipids), and secondary damage is due to the cytotoxic and mutagenic action released during lipid oxidation. The released products bind to DNA and are directly involved in the processes of mutagenesis and carcinogenesis. Therefore, oxidative stress is responsible for many diseases and contributes to their complications. Free radicals, responsible for oxidative stress, are involved in many diseases such as asthma, cancer, cataracts, cardiovascular disease [36]. The phenomenon of oxidative stress is known worldwide, due to the progression of cancer in all continents, and a remedy used in $80 \%$ worldwide for the prevention and treatment of diseases caused by oxidative stress is represented by medicinal plants [49].

\section{Contamination of medicinal plants with heavy metals}

Despite medicinal plants are consumed as natural medical, food, and nutritional sources, they can be contaminated with different pollutants, organic or inorganic. For example, persistent inorganic pollutants, such as heavy metals, are considered a category of a great interest because of their negative impacts in the environment and for human health. Unlike many organic pollutants as biodegradable organic compounds, which can degrade into carbon dioxide and water, heavy metals can be accumulated in the environment, and can induce a number of negative effects on the environment and human health, as mentioned above. Although some medicinal plants are harvested from the wild, their cultivation for commercial purposes has grown directly in proportion to the requirement [50]. The use of pesticides and the storage conditions of medicinal plants after they are harvested, can increase accumulation of heavy metals in the plant tissues.

\subsection{Interactions between soil heavy metals and medicinal plants}

Soil is the main source of contamination, where from heavy metals can move to the surface of the roots by diffusion or ion exchange between the surface of the root and soil-water. Plants use active absorption to assimilate essential metals, but they can also take up other toxic elements available in the soil (Figure 1) [51]. At the same time, heavy metals can move through cationic channels in the cell membrane inside the cell $[16,52,53]$. Heavy metals such as arsenic (As), lead (Pb), cadmium $(\mathrm{Cd})$ and mercury $(\mathrm{Hg})$ are not biologically important in living organisms, but can have toxic effects and cause 
problems in their development. For this reason, a number of heavy metals should be considered a potential threat to medicinal plants and human health [54]. Metals can be absorbed and transported from polluted soil into plants through several mechanisms: phytoextraction, phytostabilization, phytovolatilization, rhizofiltration and produce some changes in plants (Figure 2).

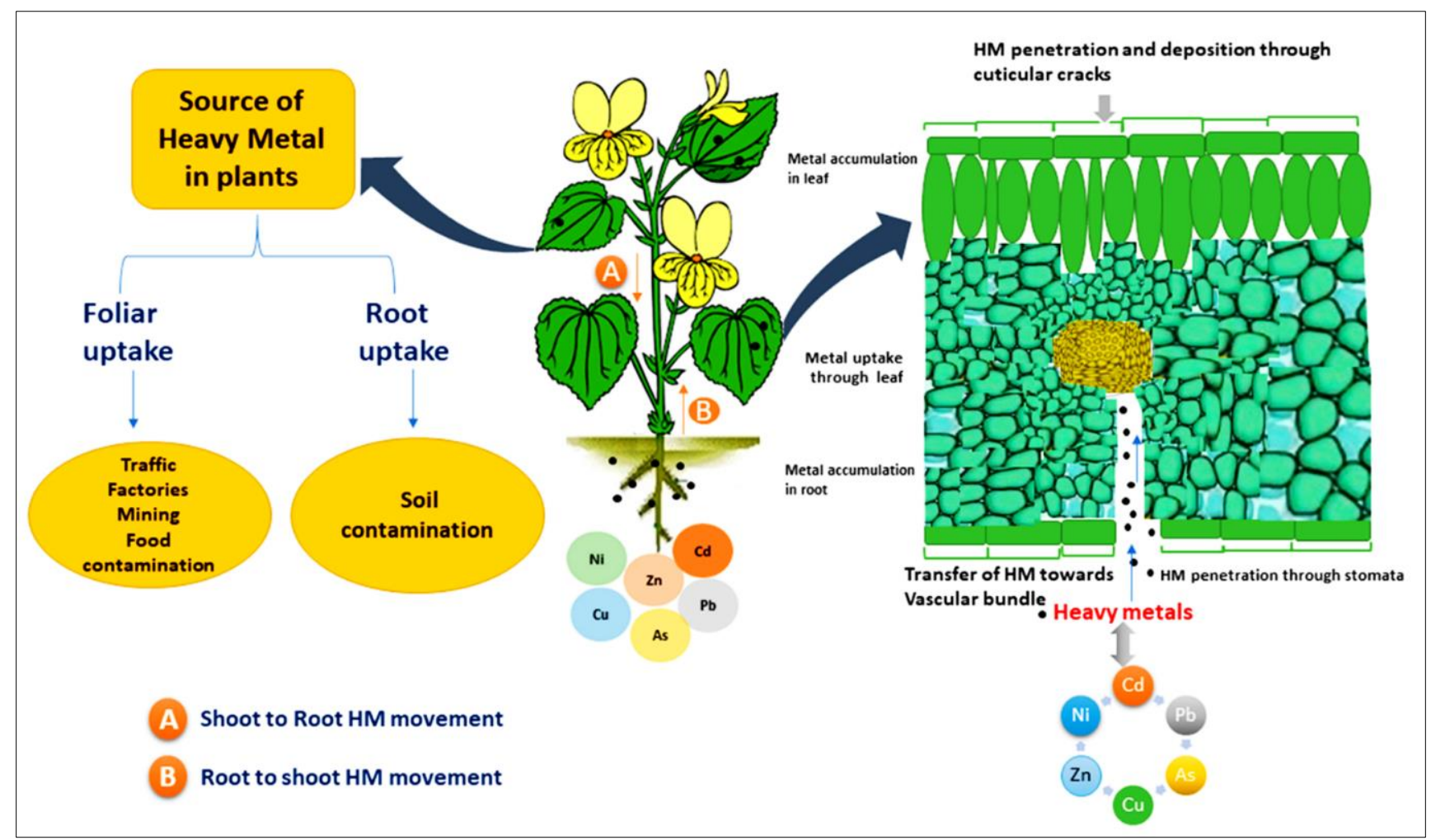

Figure 1. Sources of heavy metals, and foliar, root uptake of heavy metals in plants (from Hasan et al. [51], according to the provisions MDPI "This is an open access article distributed under the Creative Commons Attribution License which permits unrestricted use, distribution, and reproduction in any medium, provided the original work is properly cited")

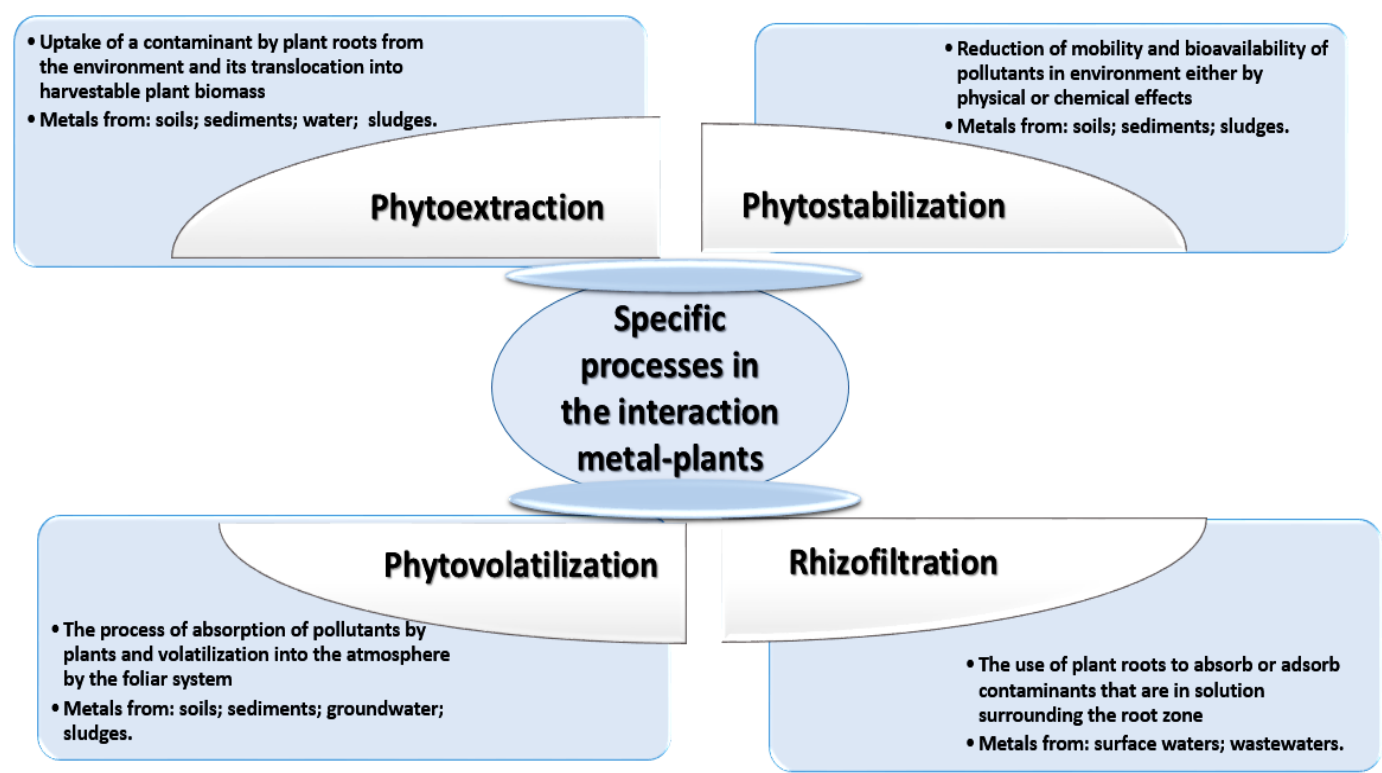

Figure 2. Metals-plants interactions during metal transport from polluted medium to plant 
A methodology to assess the mobility of metal in plants is the based on transfer (or translocation) factor $(T F)$, as expressed by Eq. (1) $[17,55]$ :

$$
T F=\frac{C_{\text {plant }}}{C_{\text {total/soil }}}
$$

where: $C_{\text {plant }}$ is the concentration of an element in the plant material (dry weight basis) and $\mathrm{C}_{\text {total/soil }}$ is the total concentration of the same element in the soil (dry weight basis) where the plant was grown. The higher the TF value, the higher the metal availability is.

On the other hand, two bioaccumulation factors $(B A F)$ were calculated. The $B A F$ in root $\left(B A F_{\text {root }}\right)$ was defined as the ratio of metal concentration in the root $\left(C_{\text {root }}\right)$ to that in the soil $\left(C_{\text {soil }}\right)$; the BAF in aerial part $\left(B A F_{\text {aerial }}\right)$ was calculated as the ratio of metal concentration in the aerial part of the plant $\left(C_{\text {aerial }}\right)$ to that in the soil $\left(C_{\text {soil }}\right)($ Eq. 2) [56]:

$$
B A F_{\text {root }}=C_{\text {root }} / C_{\text {soil }}
$$

Metal extraction ratio (MER) can be computed by Eq. (3) [57]:

$$
M E R=\left(C_{\text {plant }} \times M_{\text {plant }} / C_{\text {soil }} \times M_{\text {rooted zone }}\right) \times 100
$$

where: $C_{\text {plant }}$ is metal concentration in the harvested component of the plant biomass; $M_{\text {plant }}$ is the mass of the harvestable aboveground biomass produced on the harvest; $C_{\text {soil }}$ is the metal concentration in the soil volume; $M_{\text {rooted zone }}$ is the mass of the soil volume rooted by the species under study.

Table 2 shows some bioaccumulation parameters of various combinations heavy metals - herbs.

\begin{tabular}{|c|c|c|c|}
\hline Medicinal plant & Metal & Bioaccumulation parameters & Reference \\
\hline \multirow{4}{*}{ Artemisia vulgaris } & & $\mathrm{BAF}=2.71$ & \multirow{6}{*}{ [57] } \\
\hline & $\mathrm{Pb}$ & $\mathrm{TF}=2.46$ & \\
\hline & & MER $=3.94$ & \\
\hline & & $\mathrm{BAF}=2.13$ & \\
\hline \multirow{2}{*}{ Plectranthus amboinicus } & $\mathrm{Pb}$ & $\mathrm{TF}=0.81$ & \\
\hline & & MER $=31.0$ & \\
\hline & $\mathrm{Al}$ & $\mathrm{BAF}=0.025$ & \multirow{4}{*}{ [58] } \\
\hline Ocimum sanctum & $\mathrm{Mg}$ & $\mathrm{BAF}=0.338$ & \\
\hline \multirow[b]{2}{*}{ Aloe barbadensis } & $\mathrm{Al}$ & $\mathrm{BAF}=0.013$ & \\
\hline & $\mathrm{Mg}$ & $\mathrm{BAF}=0.205$ & \\
\hline \multirow{3}{*}{ Ocimuт tenuiflorum } & $\mathrm{Cd}$ & $\mathrm{C}=0.64\left(\mu \mathrm{g} \mathrm{g}^{-1}\right)$ & \multirow{6}{*}{ [59] } \\
\hline & $\mathrm{Pb}$ & $\mathrm{C}=13\left(\mu \mathrm{g} \mathrm{g}^{-1}\right)$ & \\
\hline & $\mathrm{Cr}$ & $\mathrm{C}=18.63\left(\mu \mathrm{g} \mathrm{g}^{-1}\right)$ & \\
\hline \multirow{3}{*}{ Rosa rubiginosa } & $\mathrm{Cd}$ & $\mathrm{C}=0.74\left(\mu \mathrm{g} \mathrm{g}^{-1}\right)$ & \\
\hline & $\mathrm{Pb}$ & $\mathrm{C}=51.77\left(\mu \mathrm{g} \mathrm{g}^{-1}\right)$ & \\
\hline & $\mathrm{Cr}$ & $\mathrm{C}=47.18\left(\mu \mathrm{g} \mathrm{g}^{-1}\right)$ & \\
\hline \multirow{3}{*}{ Rumex acetosa } & & $\mathrm{TF}=1.35$ & \multirow{3}{*}{ [60] } \\
\hline & $\mathrm{Cd}$ & $\mathrm{BAF}=0.11$ & \\
\hline & $\mathrm{Cu}$ & $\begin{array}{l}\mathrm{TF}=1.03 \\
\mathrm{BAF}=0.19\end{array}$ & \\
\hline
\end{tabular}

Table 2. Some parameters which can characterize the mobility of heavy metals from soil in different medicinal plants

\subsection{Heavy metals bioavailability for medicinal plants}

There are two possibilities for plants to interact to heavy metals: exclusion or accumulation. By accumulation, metal ions are retained in plant cells in a non-toxic form. Exclusion involves falling 
leaves to remove accumulated ions or metal complexes [7, 30, 61]. Plants extract from the soil and bioaccumulate the fraction of heavy metals that can be mobilized from the soil, the so-called available fraction, which confers to metals the property named metal bioavailability, i.e. the degree to which a chemical can be absorbed by a living organism and transported inside that organism [6, 17]. This property is dependent on the properties of the soil $(p \mathrm{H}$, organic matter content, texture) and the plant.

"Bioavailability is ... the extent to which a substance can be absorbed by a living organism and can cause an adverse physiological or toxicological response; ... this definition implicitly includes the extent to which a substance can desorb, dissolve, or otherwise dissociate from the environmental medium in which it occurs to become available for absorption." [62]. "Bioavailability processes are ... individual physical, chemical, and biological interactions that determine the exposure of plants and animals to chemicals associated with soils and sediments" [63].

Some authors considered that bioavailability is a dynamic process and that it occurs as a result of the existence of 3 successive processes: (1) a process (desorption, solubilization) controlled by physico-chemical parameters, which depends on the characteristics of the soil (for example), the metal and the interaction between the two partners, the soil and the metal (called the availability of the environment); (2) an absorption process controlled by the soil-plant relationship (physiological process, called environmental bioavailability); (3) a process of accumulation of metal inside the body, controlled by the characteristics of the organism (called toxicological bioavailability) [64-66]. Therefore, bioavailability can be characterized as a complex, dynamic process that depends on the type of organism, the type of exposure and the speciation of metals (Figure 3) [67]. In the literature there are also other definitions for bioavailability, which indicates that this concept is not thorough and constant defined. Bioavailability can be determined by chemical methods, mainly in order to predict the degree of absorption of soil pollutants in plants. These methods are summarized in Table 3 [67, $68]$.

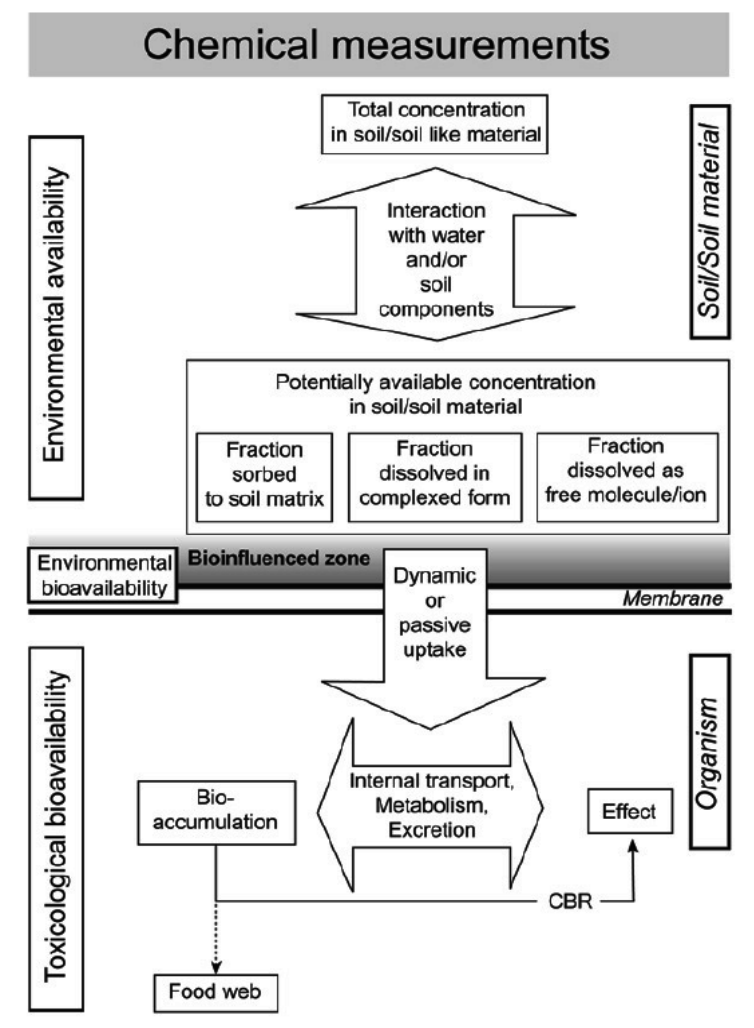

Biological measurements
Figure 3. Dynamics of bioavailability occurring in three successive processes: from total concentration in soil to effect (CBR, critical body residue) (used based on John Wiley and Sons License No. 4838990946740 on 30

May, 2020) 
Table 3. Chemical methods to predict the bioavailable fraction $(+=$ promising) [67] (Harmsen, 2007)*

\begin{tabular}{|c|c|c|c|c|c|c|c|}
\hline \multirow{2}{*}{ Mechanism } & \multirow{2}{*}{ Simulates } & \multirow{2}{*}{ Pathway } & \multirow{2}{*}{ Method } & \multicolumn{2}{|c|}{ Calibrated } & \multirow{2}{*}{$\begin{array}{l}\text { Recom- } \\
\text { mended }\end{array}$} & \multirow{2}{*}{ Limitations } \\
\hline & & & & Contaminant & Target & & \\
\hline \multirow[t]{3}{*}{$\begin{array}{l}\text { Neutral } \\
\text { extract }\end{array}$} & $\begin{array}{c}\text { pore water } \\
\text { concentration }\end{array}$ & $\begin{array}{l}\text { direct contact } \\
\text { with water }\end{array}$ & $\begin{array}{c}\text { neutral water } \\
\text { extract } \\
\left(\mathrm{NaNO}_{3} ;\right. \\
\mathrm{KNO}_{3} \mathrm{NH}_{4} \mathrm{NO}_{3} ; \\
\left.\mathrm{CaCl}_{2}\right)\end{array}$ & $\mathrm{Cd} / \mathrm{Zn} / \mathrm{Ni}$ & $\begin{array}{l}\text { soil organisms, } \\
\text { plant uptake }\end{array}$ & + & $\begin{array}{c}\mathrm{NH}_{4} \mathrm{NO}_{3} \text { may } \\
\text { reduce pH in low } \\
\text { buffered soils } \\
\mathrm{CaCl}_{2} \text { may reduce } \\
\text { dissolved organic } \\
\text { carbon } \\
\text { concentrations } \\
\text { poorly soluble } \\
\text { compounds } \\
\text { depends on } \\
\text { concentration of } \\
\text { salt }\end{array}$ \\
\hline & & $\begin{array}{l}\text { direct contact } \\
\text { with water }\end{array}$ & $\begin{array}{l}\text { extraction of } \\
\text { pore water }\end{array}$ & $\mathrm{Cd} / \mathrm{Zn} / \mathrm{Ni}$ & $\begin{array}{l}\text { soil organisms, } \\
\text { plant uptake }\end{array}$ & + & $\begin{array}{c}\text { pore water not } \\
\text { available in dry } \\
\text { soil } \\
\text { equilibration time } \\
\text { if water is added }\end{array}$ \\
\hline & & transport & leaching test & $\begin{array}{l}\text { inorganic/ } \\
\text { organic }\end{array}$ & groundwater & + & $\begin{array}{l}\text { poorly soluble } \\
\text { compounds }\end{array}$ \\
\hline $\begin{array}{c}\text { Separation } \\
\text { by diffusion }\end{array}$ & $\begin{array}{c}\text { free metal } \\
\text { concentration }\end{array}$ & uptake & $\mathrm{DMT} \dagger, \mathrm{DGT} \ddagger$ & inorganic & $\begin{array}{l}\text { soil organisms, } \\
\text { plant uptake }\end{array}$ & + & $\begin{array}{l}\text { specialized } \\
\text { equipment }\end{array}$ \\
\hline \multirow[t]{2}{*}{$\begin{array}{c}\text { Acid } \\
\text { extraction }\end{array}$} & $\begin{array}{l}\text { potential } \\
\text { soluble in } \\
\text { water }\end{array}$ & uptake & $\begin{array}{l}\text { acid extract } \\
\text { (HNO3) }\end{array}$ & $\mathrm{Cd} / \mathrm{Zn} / \mathrm{Ni}$ & $\begin{array}{l}\text { plant uptake } \\
\text { after including } \\
\text { soil } \\
\text { characteristics }\end{array}$ & + & \\
\hline & & $\begin{array}{l}\text { transport } \\
\text { uptake }\end{array}$ & $\begin{array}{c}\text { leaching test } \\
\text { acid extract ( } \mathrm{pH} \\
\text { of stomach or } \\
\text { lower) }\end{array}$ & $\begin{array}{c}\text { inorganic } \\
\mathrm{Pb}\end{array}$ & $\begin{array}{l}\text { groundwater } \\
\text { screening, } \\
\text { human } \\
\text { ingestion }\end{array}$ & $\begin{array}{l}+ \\
+\end{array}$ & $\begin{array}{l}\text { gives a maximum } \\
\text { of bioavailability } \\
\text { because } \\
\text { pH in the } \\
\text { intestine system } \\
\text { is higher }\end{array}$ \\
\hline $\begin{array}{c}\text { Complexing } \\
\text { agent }\end{array}$ & $\begin{array}{l}\text { potential } \\
\text { soluble in } \\
\text { water, } \\
\text { competitive }\end{array}$ & uptake, transport & EDTA extract & heavy metals & $\begin{array}{l}\text { plant uptake, } \\
\text { groundwater }\end{array}$ & & \\
\hline $\begin{array}{l}\text { Simulation } \\
\text { of digestion }\end{array}$ & oral uptake & human uptake & $\begin{array}{l}\text { stomach and } \\
\text { intestine system }\end{array}$ & $\begin{array}{c}\mathrm{Pb} / \mathrm{Cd} / \mathrm{Zn} / \\
\mathrm{Ni} / \mathrm{Hg} / \\
\mathrm{PCB} / \\
\text { PAH method } \\
\text { comparison }\end{array}$ & human & + & \\
\hline \multirow[t]{2}{*}{$\begin{array}{l}\text { Adsorption } \\
\text { to } \\
\text { competitive } \\
\text { adsorbant }\end{array}$} & $\begin{array}{l}\text { amount in } \\
\text { equilibrium } \\
\text { with } \\
\text { pore water }\end{array}$ & $\begin{array}{l}\text { contact with } \\
\text { pore water }\end{array}$ & $\begin{array}{c}\text { adsorption to } \\
\text { excess solid } \\
\text { phase } \\
\text { (TENAX, XAD, } \\
\text { cyclodextrins) }\end{array}$ & PAH§ & $\begin{array}{l}\text { degrading } \\
\text { organisms, } \\
\text { uptake } \\
\text { invertebrates }\end{array}$ & + & \\
\hline & $\begin{array}{c}\text { pore water } \\
\text { concentration }\end{array}$ & $\begin{array}{l}\text { contact with } \\
\text { pore water }\end{array}$ & $\begin{array}{l}\text { adsorption to } \\
\text { solid phase } \\
\text { (SPME ††) }\end{array}$ & $\begin{array}{c}\text { PAH/PCBII/ } \\
\text { OCP\# }\end{array}$ & $\begin{array}{c}\text { uptake } \\
\text { invertebrates }\end{array}$ & + & \\
\hline $\begin{array}{l}\text { Increasing } \\
\text { solubility }\end{array}$ & $\begin{array}{l}\text { amount in } \\
\text { equilibrium } \\
\text { with pore } \\
\text { water }\end{array}$ & $\begin{array}{l}\text { contact with } \\
\text { pore water }\end{array}$ & $\begin{array}{c}\text { mild (water }+ \\
\text { organic) solvent }\end{array}$ & PAHs & $\begin{array}{l}\text { degrading } \\
\text { organisms }\end{array}$ & & \\
\hline $\begin{array}{l}\text { Partial } \\
\text { oxidation of } \\
\text { organic } \\
\text { matter }\end{array}$ & $\begin{array}{l}\text { amount of } \\
\text { weakly } \\
\text { bounded } \\
\text { organic } \\
\text { contaminants }\end{array}$ & $\begin{array}{l}\text { easily attainable } \\
\text { by } \\
\text { microorganisms }\end{array}$ & $\begin{array}{l}\text { oxidation with } \\
\text { persulphate }\end{array}$ & PAHs & $\begin{array}{l}\text { degrading } \\
\text { organisms }\end{array}$ & + & \\
\hline
\end{tabular}

$\dagger$ DMT, Donnan membrane technique (Weng et al., 2005); $\$$ DGT, differential gradients in thin films; $\S$ PAH, polycyclic aromatic hydrocarbons; PCB, polychlorinated biphenyls; \# OCP, organochlorine pesticides; $\uparrow \uparrow$ SPME, solid-phase micro-extraction. *Used based on John Wiley and Sons License 4838990946740 on 30 May, 2020 


\subsection{Heavy metal-mediated changes in medicinal plants}

Some metals $(\mathrm{Cr}, \mathrm{Mn}, \mathrm{Zn}$ and $\mathrm{Cu})$ appear in green plants as essential metals usually in low concentrations, and organisms that consume such plants are not affected. However, due to environmental pollution, concentration of heavy metals in plants can be increased. A list of the most common essential and toxic heavy metals are presented in Table 4.

Exposure to heavy metals causes the accumulation of harmful reactive oxygen species (ROS), a situation when plants activate their metabolic activities and physiological changes to combat the effects of stress generated by heavy metals (Figure 4) [69]. In this way the plant protects itself against the action of free radicals, preventing the destruction of some molecules of lipids, proteins, nucleic acids [15]. Strategies for protecting plants against the action of heavy metals include the accumulation of secondary metabolites, such as antioxidant enzymes, proline, glutathione and phenolic compounds and flavonoids. These strategies depends on both the species of the plant and the concentration of the possible contaminating metal [70] (Maleki et al., 2017).

Heavy metals absorption interferes with that of nitrogen, phosphorus and potassium and may cause deficiency of these macronutrients. For example, exposure to high concentrations of cadmium can cause chlorosis and necrosis [70]. Both micronutrients and macronutrients play a very important role in the physical and biochemical processes of plants, such as chlorophyll biosynthesis, photosynthesis, DNA synthesis, protein modification, and redox reactions. For example, $\mathrm{Zn}$, a metal essential for plant development is a cofactor for more than 300 enzymes and 200 transcription processes, is associated with maintaining membrane permeability and cell reproductive function [41].

Table 4. Representative essential and toxic heavy metals in the environment

\begin{tabular}{|c|c|}
\hline \multicolumn{2}{|c|}{ Heavy metals } \\
\hline Essential & Toxic \\
\hline Zinc & Arsenic \\
\hline Copper & Cadmium \\
\hline Iron & Chromium \\
\hline Manganese & Copper \\
\hline Nickel & Lead \\
\hline Chromium & Nickel \\
\hline Molybdenum & Mercury \\
\hline
\end{tabular}

A study made by Anyanwu et al. [69] shows that some heavy metals can reduce the toxic effects of other heavy metals. For example, selenium supplementation ( $\mathrm{Se}$ ) in some plants neutralized the negative effects of cadmium (Cd), and moreover, cadmium decreased protein content, and selenium supplementation increased again to appreciable levels. An important outcome is that the growth of medicinal plants in contaminated environments with heavy metals can affect the biosynthesis of secondary metabolites, which are also important indicators for the quality of medicinal materials. Studies have shown that medicinal plants subjected to heavy metals stress cause a significant increase in secondary metabolites, which do play an essential role in plant activity, being also important in its interaction with the environment and in the ability to defend and adapt, being responsible for specific odors, color of plants, toxins, but also for tastes [71]. 


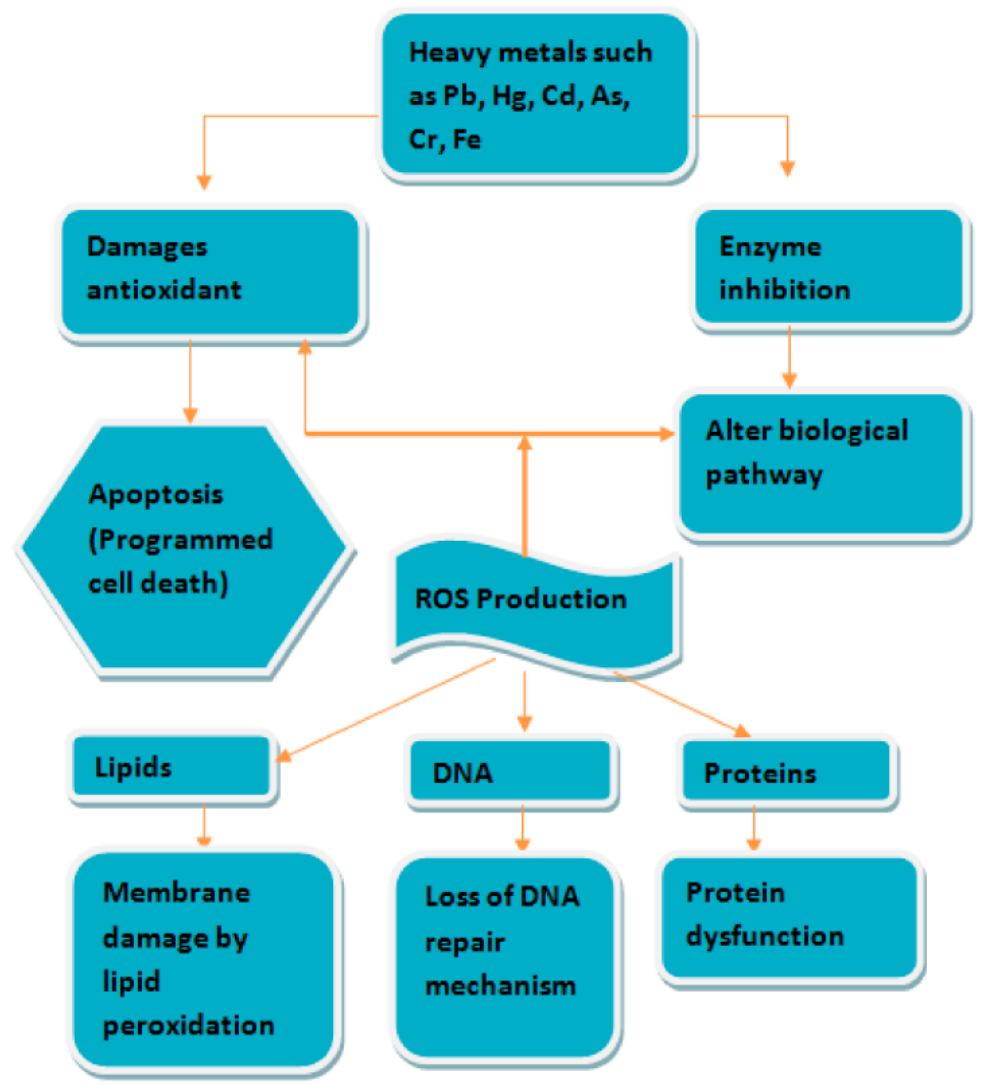

Figure 4. Attack of heavy metals on a cell resulting

in the production of reactive oxygen species (ROS). (from Anyanwu et al. [69], according to the provisions MDPI: "This is an open access article distributed under the Creative Commons Attribution License which permits unrestricted use, distribution, and reproduction in any medium, provided the original work is properly cited")

Plants produce a multitude of structurally different organic compounds that are not involved in normal growth or reproduction, but are necessary in adapting plants to the environment. Secondary metabolites contain more than one functional group and have multiple functionality and bioactivity. Synthesis of secondary metabolites derives from the primary metabolism. The environment quantitatively affects the metabolic process of plants through the impact on their development. These environmental factors can trigger sudden activation in the production of secondary metabolites [20]. Secondary plant metabolites can provide protection for plants under various biotic and abiotic influences. Environmental conditions that affect the amount or composition of phytochemicals in medicinal plants to be counteracted by phenolic compounds and other secondary metabolites, which have numerous pharmacological properties, positively influencing the medicinal potential of the plant product. Some of the secondary metabolites that contain nitrogen compounds are glycosides, alkaloids, phenolic compounds, phenolic acids, lignin and anthocyanidin. Accumulation of secondary metabolites occurs when plants are subjected to stressors such as growing conditions, photoperiod, temperature, but also at exposure to heavy metals. It has been observed that metallic stress causes increases in secondary metabolites. For example a study by Lajayer et al. [71] show that exposure to metallic stress caused the accumulation of secondary metabolites in Mentha pulegium L. by stimulating immune responses. However, scientific information regarding the specific physiological responses of medicinal plants to the toxic action of heavy metals in soils, as well as changes in the pharmacological efficacy of the plant are quite limited $[72,73]$. 


\subsection{Parts of plants affected by heavy metals}

Biological particularities of plants allow the accumulation of toxic compounds in different compartments such as root, shoot or leaf (Figure 1). Some plants show visible toxic effects such as necrosis, while other plants show no visible effects, which requires chemical analysis. Some studies show that certain species of medicinal plants have different bioaccumulative potentials (Table 5). For example Galal and Shehata [74] showed that Pltantago major is a hyperaccumulator of iron ( $\mathrm{Fe}$ ) and aluminum (Al), because can accumulated concentrations higher than $1000 \mathrm{mg} \mathrm{kg}^{-1}$, in the shoot. Another study by Angelova et al. [75] concluded that lavender (Lavandula vera L.), can tolerate heavy metal and can be considered a hyperaccumulative plant for $\mathrm{Pb}, \mathrm{Cd}$ and $\mathrm{Zn}$ and can be successfully used in the phytoremediation for heavy metal polluted soils. A study by Lajayer et al. [76] showed that edible parts of the basil plant can accumulate small amounts of micronutrients and heavy metals, while the study of Fattahi et al. [77] shows that sweet basil development was significantly affected by contaminated soil with $\mathrm{Cd}$ and $\mathrm{Pb}$. In addition, cultivation of sweet basil in contaminated soils and fields that are irrigated with wastewater can cause undesirable effects on seed germination and also on plant morphology and physiology.

The study of Fattahi et al. [77] showed that increased concentrations of $\mathrm{Cd}$ and $\mathrm{Pb}$ in the soil also lead to increased metal content in leaf and root samples. The content of heavy metals was higher in leaves than in the roots, while the concentration of $\mathrm{Pb}$ in the plant tissue was higher than the concentration of $\mathrm{Cd}$. The standard level allowed for $\mathrm{Pb}$ and $\mathrm{Cd}$ in basil leaves is $0.1-0.3 \mathrm{mg} \mathrm{kg}^{-1}$ dry weight. Another study by Gajalakshmi et al. [82] showed that Balanites aegyptiaca can accumulate a high level of copper in the leaves. However, the accumulation of heavy metals in different parts of the plant is dependent on the plant species, but the most reported cases demonstrated that the accumulation of metals occurs predominantly in leaves, which are habitually used for tea [83].

Table 5. Medicinal plant parts affected by heavy metals

\begin{tabular}{|c|c|c|c|}
\hline Species & Toxic Compounds & Affected part & Reference \\
\hline Ocimum basilicum & $\mathrm{Pb}, \mathrm{Cd}$ & Leaf $>$ root & {$[77]$} \\
\hline Pltantago major & $\mathrm{Fe}, \mathrm{Al}$ & Shoot & {$[74]$} \\
\hline Mentha spicata & $\mathrm{Cd}$ & Leaf $>$ stem & {$[78]$} \\
\hline Calendula officinalis & $\mathrm{Cu}$ & Leaf & {$[79]$} \\
\hline Mentha & $\mathrm{Cd}$ & Leaf, stem & {$[80]$} \\
\hline Matricaria chamomilla & $\mathrm{Cd}$ & Leaf & {$[81]$} \\
\hline Balanites aegyptiaca & $\mathrm{Cu}$ & Leaf & {$[82]$} \\
\hline
\end{tabular}

\section{Risks generated by heavy metals in ecosystems and humans}

It is estimated that over $70 \%$ of the world's population uses herbs to treat a condition. However, various studies have shown that they can be a source of risk to human health as a result of exposure to a number of toxic elements contained in plants and taken from the environment. Soil pollution with heavy metals can generate directly or indirectly, through harvested plants, dangers and risks to ecosystems and human health through: food chain (soil-plant-human or soil-plant-animal-human), direct ingestion, decreased agricultural production due to phytotoxicity, decreased land use for agriculture $[84,85]$.

\subsection{Medicinal plants - a source of heavy metals in human body}

The deep knowledge of herbal remedies in traditional cultures has been developed on the basis of many centuries of trials and passed down the preparation and use of herbs, from one generation to another. Modern allopathic medicine has its roots in this traditional culture. In traditional systems that use herbal medicines, their preparation is standardized and varies depending on the plant species and what condition is treated. After processing and conditioning of medicinal plants for use, the heavy metals they contain enter the human body and can cause dysfunction of the central nervous system, liver, lungs, heart, kidneys and brain. 
Medicinal plants can be prepared in by infusion (hot teas), tinctures (in alcohol and water), decoctions (boiled tea) and macerated (obtained by cold soaking). Plant-derived substances have become of great interest due to their versatile applications. Medicinal plants are the richest sources of drugs in traditional systems, they are used in modern drugs, chemical entities for synthetic drugs and food supplements. WHO recommends, encourages and promotes traditional herbal remedies in national health care programs because of their low cost and the fact that people trust them [86]. However, there is a possibility that the medicinal plants used may be contaminated with heavy metals and by consumption, especially by preparing herbal teas harvested from soils whose chemical properties are not known.

Recent studies show that some medicinal plants can accumulate significant amounts of heavy metals in their components, which will then be used for consumption by the population. In Romania, Nica Badea [87] investigated the concentration and dispersion of heavy metals $\mathrm{Pb}, \mathrm{Cd}, \mathrm{Hg}$, in some medicinal herbs as: Chelidonium majus L, Crataegus monogyna, Artemisia absinthium L, Hypericum perforatum, from spontaneous flora bordering coal power plants and, based on the results, recommended a systematic control of heavy metals content in herbs. Diaconu et al. [88] performed quantitative analyses of metallic elements $(\mathrm{Cu}, \mathrm{Cr}, \mathrm{Cd}, \mathrm{Fe}, \mathrm{Mn}, \mathrm{Zn}, \mathrm{Pb})$ in some medicinal plants comprising Mentha piperita L., Matricaria camomilla L., Hypericum perforatum L., Achillea millefolium L., Thymus serpillum, Capsella-bursa-pastoris L., Urtica dioica L., Primula veris L., Plantago major L., Taraxacum officinalis L., and their infusions, using flame absorption spectrometry. It was found that monitoring the content of mineral elements in medicinal plants and their boiling water extracts is necessary due to high concentration of heavy metals in herbs infusion. Muntean et al. [89] analyzed the heavy metal content of some commercially available products: basil (Basilici folium), chamomile (Chamomillae folium), mulberry (Mori folium), plantain (Plantaginis folium), dandelion (Taraxaci herba), mint (Menthae herba), St. John's wort (Hyperici herba), marigold (Calendula flos), fennel (Foeniculi fructus) and dill (Anethi fructus). The heavy metals contents of herbal teas and drinks was found as varying with factors as plants species, geographical area, exposure to different pollution sources, drying conditions.

Tea has an important role in the intestinal micro flora and is one of the most consumed beverages in the world. It has a beneficial action on intestinal diseases and in the protection of cell membranes due to oxidative damage. The conditions which tea are cultivated can favor the assimilation of a heavy metal content. By storing tea through bulk storage leads to the accumulation of heavy metals, especially in black tea. There are studies showing the presence of heavy metals in tea samples made by medicinal plants. For example, Ghazala et al. [90] showed that following a sample collected from a source with a concentration of $5,804 \mathrm{ppm}$, he obtained THQ (target risk quotient) over 1 , demonstrating that tea consumption can present a risk to human health due to the exceeded concentration of toxic heavy metals. Another study by Diaconu et al. [88] showed that in the tea sample the highest level of heavy metal was iron, between $16.88 \pm 0.87 \mathrm{mg} / \mathrm{L}$ in Urtica dioica L. A study by Mahmoud et al. [91] show that a certain brand of black tea contains the digested samples with the highest amounts of $\mathrm{Mn}(1128.5 \pm 77.9 \mu \mathrm{g} / \mathrm{g}) \mathrm{Fe}(269.0 \pm 14.1 \mu \mathrm{g} / \mathrm{g})$ and $\mathrm{Zn}(29,6 \pm 2.0 \mu \mathrm{g} /$ $\mathrm{g})$ and in the infused samples Mn $(206.1 \pm 8.1 \mu \mathrm{g} / 100 \mathrm{ml})$, Fe $(3.0 \pm 1.16 \mu \mathrm{g} / 100 \mathrm{ml})$ and $\mathrm{Zn}(6.2 \pm$ $1.0 \mu \mathrm{g} / 100 \mathrm{~mL}$ ), which means in the infused samples the quantities of metals are much smaller. Brima [92] studied the levels of four metals ( $\mathrm{Al}, \mathrm{Pb}$, As, and $\mathrm{Cd}$ ) in several herbs: lemongrass (Cymbopogon), sagebrush (Artemisia), harjal (Cynanchum argel delile), horsetail (Equisetum), and chestnut lilac (Vitex agnus-castus), and analyzed using inductively coupled plasma mass spectrometry (ICP-MS). The medicinal plants proved to be a source of exposure to toxic elements.

The use of medicinal plants as components of cosmetics may generate health risks for users. At present, there is an increase in the attractiveness of cosmetic products that contain active principles extracted from medicinal plants, being considered safer for human health than those obtained by synthesis. However, these products are often prepared from self-harvested vegetable ingredients from the natural environment and can contain heavy metals (most commonly $\mathrm{Pb}, \mathrm{Cd}, \mathrm{Hg}, \mathrm{Cr}, \mathrm{Ni}, \mathrm{Cu}$ ) that 
are transferred to cosmetics (shampoos, creams, makeup products). The effect of heavy metals on the skin or the accumulation in the body after absorption can generate systemic toxic effects, which can be augmented by the presence of ingredients specific to the respective products [92-94].

\subsection{Potential risks for human health}

There are several ways for heavy metals to enter in the human body, including dust inhalation, soil ingestion, dermal contact, and the consumption of plants grown on contaminated soil. Into human body, heavy metals present an increased risk of cardiovascular, neurological and renal diseases. Studies show that a major route of exposure to heavy metals is the consumption of contaminated food. Worldwide, more than 420,000 people die each year after eating contaminated food, and one from ten people get sick. Consumption of contaminated food can cause more than 200 risks of acute and chronic diseases, from digestive infections to cancer [95]. Numerous studies have shown that heavy metals exert dangerous effects on human health, causing cancer, damage to the nervous system, blood composition [96-98].

The interest in the effects of heavy metals on medicinal plants has increased in recent decades, articulating the acute need to monitor and analyze the condition of medicinal plants affected by the presence of heavy metals, in order to avoid health hazards. The risks to human health associated with the presence of heavy metals in medicinal plants have led to the establishment of safety standards for herbal remedies that provide for maximum permitted concentrations for some heavy metals in natural remedies [96].

Despite the fact that there are data on the content of heavy metals in plants in literature studies, there are no safe limits set by the authorities for all heavy metals. However, as a result of the toxicity of heavy metals to plants and human health and to ensure the quality of herbal medicines, teas, nutraceuticals and other herbal preparations, large-scale analyzes of the metal content of medicinal herbs have been carried out. In addition, the World Health Organization and the US Food and Drug Administration (FDA) have standardized maximum allowable limits for the concentration of certain metals (As, $\mathrm{Hg}, \mathrm{Pb}, \mathrm{Cd}$ ) in these plants, but not for all metals. Safe limits have been developed for $\mathrm{Cd}$, $\mathrm{Pb}$ and $\mathrm{Hg}$ by the European Pharmacopoeia (Ph. Eur), while World Health Organization [99] and Food and Agriculture Organization [100] have jointly proposed acceptable levels of toxic substances that can be ingested weekly, the Provisional Tolerable Weekly Intake (PTWI) [96, 30] (Table 6). The analytical results for heavy metal content in medicinal plants represent an important step to detect potentially toxic levels for heavy metals that can be dangerous for living organisms. Another important step is to know the hyperaccumulative medicinal plants, because they can absorb large amounts of metal ions and thus pose risks to human health. Plants with hyperaccumulative potential can absorb 50, 100 times more metal than normal plants. This phenomenon of hyperaccumulation is intensified if the environment has high concentrations of heavy metals. To date, 500 species of hyperaccumulating plants are recognized [30].

Table 6. Safe limit values for metals in medicinal plants established by WHO, FDA and European Pharmacopoeia (Ph. Eur)

\begin{tabular}{cccc}
\hline Metal & $\begin{array}{c}\text { WHO/FDA } \\
\text { Permissible limit }\end{array}$ & $\begin{array}{c}\text { Ph. Eur. Permissible limit } \\
\left(\mathbf{m g ~ k g}^{-1}\right)\end{array}$ & $\begin{array}{c}\text { FAO/WHO PTWI } \\
\left(\mathbf{m g ~ k g}^{-1}\right)\end{array}$ \\
\hline $\mathrm{As}$ & 10 & 1 & 15 \\
$\mathrm{Cd}$ & 0.3 & 0.5 & 7 \\
$\mathrm{Hg}$ & 1 & 0,1 & 5 \\
$\mathrm{~Pb}$ & 10 & 5 & 25 \\
\hline
\end{tabular}

There are some indicators which help in the evaluation of the potential risks due to the commonly consumed medicinal plants. The average estimated daily intake (EDI) of heavy metals ( $\mathrm{Al}, \mathrm{As}, \mathrm{Cd}, \mathrm{Cr}$, $\mathrm{Cu}, \mathrm{Fe}, \mathrm{Hg}, \mathrm{Mn}, \mathrm{Ni}, \mathrm{Pb}$, and $\mathrm{Zn}$ ), which depends on metal concentration in plants and the consumption degree of the particular plants can be calculated using Eq. (4), suggested by the US EPA [96, 101], 
where $E D I$ is the average daily intake or dose by ingestion $(\mathrm{mg} / \mathrm{kg}$ body weight/day); $C$ is the heavy metal concentration in the exposure medium $(\mathrm{mg} / \mathrm{L} \mathrm{or} \mathrm{mg} / \mathrm{kg}) ; F_{I R}$ is the daily consumption rate:

$$
E D I=C \frac{F_{I R}}{W_{A B}}
$$

The target hazard quotient (THQ) (Eq. 5) characterizes the human health risk posed by heavy metal exposure, as the ratio of the average EDI resulting from exposure to site media to the reference dose $(R f D)$ for an individual pathway and chemical [96,101]:

$$
T H Q=\frac{C \times I R \times E F \times E D}{B W \times A T \times R f D}
$$

where: $C$ is the heavy metal concentration in the exposure medium $(\mathrm{mg} / \mathrm{L} \mathrm{or} \mathrm{mg} / \mathrm{kg})$; $I R$ is the ingestion rate (L/day, or $\mathrm{kg} / \mathrm{day}$ ); $E F$ is the exposure frequency (days/year); $E D$ is the exposure duration (years, equivalent to the average lifespan); $B W$ is the body weight in kilogram; $A T$ is the average time for non-carcinogens (days/year $\times$ number of exposure years, assuming e.g. 70 years).

Risk to human health can be assessed by health risk index $(H R I)$, which can be calculated based on daily intake of the metals through consumption of the herbs $(C n \times D n)$ and then compared with the prescribed reference oral dose, where the case [102,103]. This index can be calculated using Eq. (6):

$$
H R I=\sum_{n}\left(C_{n} \times D_{n}\right) / R f D \times B_{w}
$$

where $C_{n}$ is the mean metal concentration in herbs on fresh weight basis $(\mathrm{mg} / \mathrm{kg}) ; D_{n}$ is average daily intake rate of herbs; $R f D$ is the safe level of oral exposure; $B_{w}$ is the average body weight (70 $\mathrm{kg}$ for adult). An index under 1.0 is assumed as safe.

\section{Conclusions}

Our review has shown that medicinal plants play an important role in the pharmaceutical and health care areas of the $21 \mathrm{st}$ century. Although the use of herbs is an old practice, dating back to ancient times, it still exists worldwide. However, medicinal plants may be a source of exposure to toxic elements, depending on their origin and nature, in particular creating a risk of exposure to the toxic action of heavy metals. It should be kept in mind that some heavy metals are important as micronutrients for the proper functioning of plants, but in high concentrations become toxic. Moreover, some heavy metals are toxic even at low concentrations.

Increased contamination of the environment with heavy metals inevitably causes contamination of medicinal plants. They are absorbed from soil and are transported by roots, stem to leaves, which are the most contaminated parts of plants, frequently used for the extraction of active principles from plants. The plants also develop specific defense mechanisms, which can change the chemical and physiological functions of plants, with consequences on their pharmaceutical and health care value.

Our analysis shows that medicinal plants, used as a means of treatment, a component in cosmetics, beverages etc., must be collected from areas not contaminated with heavy metals. It is therefore recommended that medicinal plants be checked for heavy metal levels before use for pharmaceutical purposes. 


\section{References}

1. ALHARBI, O.M.L., ARSHBASHEER, A., KHATTAB, R.A., ALI, IHealth and environmental effects of persistent organic pollutants, J. Mol. Liq., 263, 2018, 442-453.

https://doi.org/10.1016/j.molliq.2018.05.029

2. GAVRILESCU, M., Behaviour of persistent pollutants and risks associated with their presence in the environment - integrated studies, Environ Eng. Manag. J, 8, 2009, 1517-1531.

http://doi.org/10.30638/eemj.2009.221

3.GAVRILESCU, M., DEMNEROVÁ, K., AAMAND, J., AGATHOS, S., FAVA, F., Emerging pollutants in the environment: present and future challenges in biomonitoring, ecological risks and bioremediation, New Biotechnol., 32, 2015 147-156. http://dx.doi.org/10.1016/j.nbt.2014.01.001

4. FIEDLER, H., (2008), Stockholm Convention on POPs: Obligations and Implementation, In: The Fate of Persistent Organic Pollutants in the Environment, Mehmetli E., Koumanova B. (eds), NATO Science for Peace and Security Series, Springer, Dordrecht.

5. GAVRILESCU, M., Biosorption in Environmental Remediation. In: Bioremediation Technology: Recent Advances, Fulekar, M.H. (Ed.), Springer, New York, 2010, 35-99. https://doi.org/10.1007/97890-481-3678-0_3

6. HLIHOR, R.M., APOSTOL, L.C., SMARANDA, C., PAVEL, L.V., CALIMAN, F.A., ROBU, B.M., GAVRILESCU, M., Bioavailability processes for contaminants in soils and their use in risk assessment, Environ Eng. Manag. J, 8, 2009, 1199-1206. http://doi.org/10.30638/eemj.2009.175

7. HLIHOR, R.M., DIACONU, M., LEON, F., CURTEANU, S., TAVARES, T., GAVRILESCU, M., Experimental analysis and mathematical prediction of $\mathrm{Cd}(\mathrm{II})$ removal by biosorption using support vector machines and genetic algorithms, N Biotechnol., 32, 2015, 358-368.

http://doi.org/10.1016/j.nbt.2014.08.003

8. SPEIGHT J.G., Environmental Inorganic Chemistry for Engineers, Elsevier - ButterworthHeinemann, Kidlington, UK and Cambridge, USA, 2017. https://doi.org/10.1016/B978-0-12-849891$\underline{0.09992-6}$

9. ABDULFATTAH, M.A., ALMAHDI, M.A., ADEL, M.M., Determination of some heavy metals in four medicinal plants, World Acad Sci Eng Technol, 78, 2013, 1568.

10. ZIVKOVIK, J., RAZIC, S., ARSENIJEVIK, J., MAKSIMOVIK, Z., Heavy metals contents in Veronica species and soil from mountain area in Serbia, J. Serb. Chem. Soc., 77, 2012, 959-970. http://doi.org/10.2298/JSC111225221Z

11. YADAV, S.K., Heavy metals toxicity in plants: An overview on the role of glutathione and phytochelatins in heavy metal stress tolerance of plants, S. Afr. J. Bot., 76, 2010, 167-179. http://doi.org/10.1016/j.sajb.2009.10.007

12. PAVEL, V.L., BULGARIU, D., BULGARIU, L., HLIHOR, R.M., GAVRILESCU, M., Analysis of factors determining the behaviour of chromium in some Romanian soils, Environ Eng. Manag. J., 9, 2010, 89-94. http://doi.org/10.30638/eemj.2010.013

13. MANU, M., ONETE, M., BANCILA, R.I., The effect of heavy metals on mite communities (acari: gamasina) from urban parks - Bucharest, Romania, Environ Eng. Manag. J, 17, 2018, 2071-2081. http://doi.org/10.30638/eemj.2018.206

14. WUANA, R.A., OKIEIMEN, F.E., Heavy metals in contaminated soils: a review of sources, chemistry, risks and best available strategies for remediation, Int. Sch. Res. Notices., 2011, ID 402647. https://doi.org/10.5402/2011/402647

15. IBRAHIM, M.H., KONG, Y.C., ZAIN, N.A.M., Effect of cadmium and copper exposure on growth, secondary metabolites and antioxidant activity in the medicinal plant Sambung Nyawa (Gynura procumbens (Lour.) Merr), Molecules, 22, 2017, 1623,

http://doi.org/doi:10.3390/molecules22101623 
16. SOBARIU, D.L., FERTU, D.I.T., DIACONU, M., PAVEL, L.V., HLIHOR, R.M., DRAGOI, E.N., CURTEANU, S., LENZ, M., CORVINI, P.F.X., GAVRILESCU, M., Rhizobacteria and plant symbiosis in heavy metal uptake and its implications for soil bioremediation, New Biotechnol., 39A, 2017, 125-134. http://doi.org/10.1016/j.nbt.2016.09.002

17. INTAWONGSE, M., DEAN, J.R., Uptake of heavy metals by vegetable plants grown on contaminated soil and their bioavailability in the human gastrointestinal tract, Food Addit. Contam., 23, 2006, 36-48. http://doi.org/10.1080/02652030500387554

18.***WHO, 2019, Lead poisoning and health, World Health Organization, On line at: https://www.who.int/news-room/fact-sheets/detail/lead-poisoning-and-health

19. ETKIN, N.L. (Ed.), Plants and Indigenous Medicine and Diet: Biobehavioral Approaches, Routledge, New York, 2019.

20. NCUBE, B., FINNIE, J.F., VAN STADEN, J., Quality from the field: The impact of environmental factors as quality determinants in medicinal plants, S. Afr. J. Bot., 82, 2012, 11-20. https://doi.org/10.1016/j.sajb.2012.05.009

21. AJASA, A.M.O., BELlO, M.O., IBRAHIM, A.O., OGUNWANDE, I.A., OLAWORE, N.O., Heavy trace metals and macronutrients status in herbal plants of Nigeria, Food Chem., 85, 2004, 6771. https://doi.org/10.1016/j.foodchem.2003.06.004

22. OBI, E., AKUNYILI, D.N., EKPO, B., ORISAKWE, O.E., Heavy metal hazards of Nigerian herbal remedies, Sci. Total Environ., 369, 2006, 35-41.

http://doi.org/10.1016/j.scitotenv.2006.04.024

23. SHARMA, R.K., AGRAWAL, M., MARSHALL, F.M., Heavy metals in vegetables collected from production and market sites of a tropical urban area of India, Food Chem. Toxicol., 47, 2009, 583-591. https://doi.org/10.1016/j.fct.2008.12.016

24. SHAW, D., Risks or remedies? Safety aspects of herbal remedies in the UK, J. Roy. Soc. Med., 91, 1998, 294-296. http://doi.org/10.1177/014107689809100602

25. STREET, R.A., Heavy metals in medicinal plant products - An African perspective, S. Afr. J. Bot., 82, 2012, 67-74. http://dx.doi.org/10.1016/j.sajb.2012.07.013.

26. MANI, S., ARCHANA, S., MAHMOUD, A., MAYADA, R.F., ASHOK, M., KULDEEP, D., Beneficial health applications and medicinal values of Pedicularis plants: A review, Biomed. Pharmacother., 95, 2017, 1301-1313.

27. JUHÁS, S., BUJNAKOVA, D., REHAK, P., CIKOS, S., CZIKKOVA, S., VESELA, J., Antiinflammatory effects of thyme essential oil in mice, Acta Vet. Scand., 3, 2008, 327-334. https://doi.org/10.2754/avb200877030327

28. MOREIRA DE ALMEIDA, E., FERREIRA, H.J., ALVES, D.R., BARBOSA DA SILVA, M., Therapeutic potential of medicinal plants indicated by the Brazilian public health system in treating the collateral effects induced by chemotherapy, radiotherapy, and chemoradiotherapy: A systematic review, Complement. Ther Med, 49, 2020, https://doi.org/10.1016/j.ctim.2019.102293

29. INOUE, M., HAYASHI, S., CRAKER, L.E., Role of Medicinal and Aromatic Plants: Past, Present, and Future, In: Pharmacognosy - Medicinal Plants, Perveen S., Al-Taweel A., (Eds.), Intech, Rijeka, Croatia, 2019, 1-13. http://doi.org/10.5772/intechopen.82497

30. SARMA, H., DEKA, S., DEKA, H., SAIKIA, R.R, Accumulation of Heavy Metals in Selected Medicinal Plants, In: Reviews of Environmental Contamination and Toxicology, Whitacre D.M. (Ed.), Springer Science+Business Media, 2011, 63-86. http://doi.org/10.1007/978-1-4614-0668-6_4

31. SHABAN, S.N., ABDOU, A.K., HASSAN, N.E., Impact of toxic heavy metals and pesticide residues in herbal products, Beni-Suef Univ. J. Basic Appl. Sci., 2016.

http://doi.org/10.1016/j.bjas.2015.10.001

32. ZUO, H., LI, Y., CUI, Y., AN, Y., Cardioprotective effect of Malva sylvestris L. in myocardial ischemic/reprefused rats, Biomed. Pharmacother., 95, 2017, 679-684.

http://doi.org/10.1016/j.biopha.2017.08.111 
33. RANJBAR, M., FIROOZABADI, A., SALEHI, A., GHORBANIFAR, Z., ZARSHENAS, M.M., SADEGHNIIAT-HAGHIGHI, K., REZAEIZADEH, H., Effects of Herbal combination (Melissa officinalis L. and Nepeta menthoides Boiss. \& Buhse) on insomnia severity, anxiety and depression in insomniacs: Randomized placebo controlled trial, Integr. Med. Res., 7, 2018, 328-332.

http://doi.org/10.1016/j.imr.2018.08.001

34. GHANBARI, A., VAFAEI, A.A., NAGHIBI NASAB, F.S., ATTARMOGHADDAM, M., BANDEGI, A.R., MORANDI-KOR, N., Spirulina microalgae improves memory deficit induced by scopolamine in male pup rats: Role of oxidative stress, S. Afr. J. Bot., 127, 2019, 220-225

35. BORA, F.D., BUNEA, C., Bioacumularea Metalelor în Vița-de-Vie, Editura Bioflux, Cluj-Napoca, Romania, 2019.

36. MAURICETTE, T.L, JEREMY, P., CLAIRE, G., EDMOND, S.M, ANDRÉ, K., JEAN, M.N., JOËL, S, LOUIS, M., Ethnobotanical study of medicinal plants used by traditional healers for the treatment of oxidative stress-related diseases in the Congo Basin, J Herb Med., 13, 2018, 76-90. https://doi.org/10.1016/j.hermed.2018.05.002

37.YATOO, M.H., UMESH, D., ARUMUGAM, G., KUMARAGURUBARAN, K., MARAPPAN, G., REKHA, K., Beneficial health applications and medicinal values of Pedicularis plants: A review, Biomed. Pharmacother., 95, 2017, 1301-1313.

http://doi.org/10.1016/j.biopha.2017.09.041

38. SINGH, R., SHUSHNI, M.A.M., BELKHEIR, A., Antibacterial and antioxidant activities of Mentha piperita L., Arab. J. Chem., 8, 2015a, 322-328. https://doi.org/10.1016/j.arabjc.2011.01.019

39. KUTLU, A.K., YILMAZ, E., ÇEÇEN, D., Effects of aroma inhalation on examination anxiety, Teach. Learn. Nurs., 3, 2008, 125-130. https://doi.org/10.1016/j.teln.2008.04.005

40. SINGH, S., PARIHAR, P., SINGH, R., SINGH, V.P., PRASAD, S.M., Heavy metal tolerance in plants: role of transcriptomics, proteomics, metabolomics, and ionomics, Front. Plant Sci., 2015b, ID 1143, http://doi.org/10.3389/fpls.2015.01143

41. SINGH, H., PRAKASH, A., KALIA, ABU, A.N., MAJEED, A.B.A., Synergistic hepatoprotective potential of ethanolic extract of Solanum xanthocarpum and Juniperus communis against paracetamol and azithromycin induced liver injury in rats, J. Tradit. Complement. Med., 6, 2016, 370-376, http://doi.org/10.1016/j.jtcme.2015.07.005

42. AYOOBI, F., MOGHADAM-AHMADI, A., AMIRI, H., VAKILIAN, A., HEIDARI, M., FARAHMAND, H., FATHOLLAHI, M.S., FATEMI, I., SHAFIEI, S.A., ALAHTAVAKOLI, M., SHAMSIZADEH, A., Achillea millefolium is beneficial as an add-on therapy in patients with multiple sclerosis: A randomized placebo-controlled clinical trial, Phytomed., 52, 2019, 89-97. http://doi.org/10.1016/j.phymed.2018.06.017

43. DŽAMIĆ, A.M., SOKOVIĆ, M.D., NOVAKOVIĆ, M., JADRANIN, M., RISTIĆ, M.S., TEŠEVIĆ, V., MARIN, P.D., Composition, antifungal and antioxidant properties of Hyssopus officinalis L. subsp. pilifer (Pant.) Murb. essential oil and deodorized extracts, Ind Crops Prod, 51, 2013, 401-407. https://doi.org/10.1016/j.indcrop.2013.09.038

44. OLAS, B., BRYŚ, M., Is it safe to use Acorus calamus as a source of promising bioactive compounds in prevention and treatment of cardiovascular diseases?, Chem. Biol. Interact., 281, 2018, 32-36. https://doi.org/10.1016/j.cbi.2017.12.026

45. EATEMADNIA, A., ANSARI, A., ABEDI, P., NAJAR, S., The effect of Hypericum perforatum on postmenopausal symptoms and depression: A randomized controlled trial, Complement. Ther. Med., 45, 2019, 109-113.

46. CAUDAl, D., GUINOBERT, I., LAFOUX, A., BARDOT, V., COTTE, C., RIPOCHE, I., CHALARD, P., HUCHET, C., Skeletal muscle relaxant effect of a standardized extract of Valeriana officinalis L. after acute administration in mice, J. of Trad. Complement. Med., 8, 2018, 335-340. http://doi.org/10.1016/j.jtcme.2017.06.011 
47. MIRAJ, S., RAFIEIAN, K., KIANI, S., Melissa officinalis L.: A review study with an antioxidant prospective, J. Evid-Based Integr. Med., 22, 2017, 385-394.

http://doi.org/10.1177/2156587216663433

48. ALZOUBI, K.H., AL-JAMAL, F.F., MAHASNEH, A.F., Cerebrolysin prevents sleep deprivation induced memory impairment and oxidative stress, Physiol. Behav., 217, 2020. https://doi.org/10.1016/j.physbeh.2020.112823.

49. XU, D.P., LI, Y., MENG, X., ZHOU, T., ZHOU, Y., ZHENG, J., ZHANG, J.J., LI, H.-B., Natural antioxidants in foods and medicinal plants: extraction, assessment and resources, 2017. http://doi.org/10.3390/ijms18010096

50. TRIPATHY, V., BASAK, B.B., VARGHESE, T.S., SAHA, A., Residues and contaminants in medicinal herbs-A review, Phytochem. Lett., 14, 2015, 67-78.

https://doi.org/10.1016/j.phytol.2015.09.003

51. HASAN, M.M., UDIN, N.M, ARA-SHARMEEN, I., ALHARBY, H.F., ALZAHRANI, Y., HAKEEM, K.R., ZHANG, L., Assisting phytoremediation of heavy metals using chemical amendments, Plants, 8, 2019, 295. https://doi.org/10.3390/plants8090295

52. DIACONU, M., PAVEL, L.V., HLIHOR, R.M., ROSCA, M., FERTU, D.I., LENZ, M., CORVINI, P.X., GAVRILESCU, M., Characterization of heavy metal toxicity in some plants and microorganisms-A preliminary approach for environmental bioremediation, New Biotechnol., 56, 2020, 130-139. http://doi.org/10.1016/j.nbt.2020.01.003

53. MAHMOOD, M., MANSOUR, G., KHALIL, K., Physiological and antioxidative responses of medicinal plants exposed to heavy metals stress, Plant Gene, 11, 2017, 247-254. https://doi.org/10.1016/j.plgene.2017.04.006

54.OZDEN, H., OZDEN, S., Levels of heavy metals and Ochratoxin A in medicinal plants commercialized in Turkey, Turk. J. Pharm. Sci., 15, 2018, 376-381.

http://doi.org/10.4274/tjps.74936.

55. CHOJNACKA, K., CHOJNACKI, A., GORECKA, H., GORECKI, H., Bioavailability of heavy metals from polluted soils to plants, Sci. Total Environ., 337, 2005, 175-182.

https://doi.org/10.1016/j.scitotenv.2004.06.009

56. GARCÍA MARTIN, J.F., GONZÁLEZ CARO, M.C., LÓPEZ BARRERA, M.C., TORRES GARCÍA, M., BARBIN, D., ÁlVAREZ MATEOS, P., Metal accumulation by Jatropha curcas L. adult plants grown on heavy metal-contaminated soil, Plants, 9, 2020, 418.

http://doi.org/10.3390/plants9040418

57. ONGY, H.V., BELONIAS, B.S., Lead potential bioaccumulation in two species of commonly used medicinal plants in Leyte, Ann. Trop. Res., 40, 2018, 1-14.

https://doi.org/10.32945/atr4021.2018

58.MAHARIA, R.S., DUTTA, R.K., ACHARYA, R., REDDY, A.V.R., Heavy metal bioaccumulation in selected medicinal plants collected from Khetri copper mines and comparison with those collected from fertile soil in Haridwar, India, J. Environ. Sci. Health., Part B, 45, 2010, = 174-181. http://doi.org/10.1080/03601230903472249

59. KUMAR, N., KULSOOM, M., SHUKLA, V., KUMAR, D., KUMAR, P.S., TIWARI, J., DWIVEDI, N., Profiling of heavy metal and pesticide residues in medicinal plants, Environ. Sci. Pollut. Res., 25, 2018, 29505-29510. https://doi.org/10.1007/s11356-018-2993-Z

60.BALABANOVA, B, STAFILOV, T, BAČEVA, K., Bioavailability and bioaccumulation characterization of essential and heavy metals contents in R. acetosa, S. oleracea and U. dioica from copper polluted and referent areas, J Environ Health Sci Eng, 13(1):2, 2015.

http://doi:10.1186/s40201-015-0159-1

61. PAVEL, V.L., SOBARIU, D.L., DIACONU, M., STATESCU, F., GAVRILESCU, M., Effects of heavy metals on Lepidium sativum germination and growth, Environ. Eng. Manag. J., 12, 2013, 727733. http://doi.org/10.30638/eemj.2013.089 
62. NAVFAC, (2000), Guide for Incorporating Bioavailability Adjustments into Human Health and Ecological Risk Assessments at U. S. Navy and Marine Corps Facilities. Part 1: Overview of Metals Bioavailability, Naval Facilities Engineering Command, Washington, DC. On line at: http://www.cprm.gov.br/publique/media/gestao_territorial/geologia_medica/usnavy1.pdf

63. NRC, (2003), Bioavailability of Contaminants in Soils and Sediments: Processes, Tools, and Applications, The National Academies Press, Washington, DC, https://doi.org/10.17226/10523.

64. KIM, R.-Y., YOON, J.-K., KIM, T.-S., YANG, J.E., OWENS, G., KIM, K.R., Bioavailability of heavy metals in soils: definitions and practical implementation - a critical review, Environ. Geochem. Health, 37, 2015. http://doi.org/10.1007/s10653-015-9695-y

65. LANNO, R.,.WELLS, J., CONDER, J., BRADHAM, K., BASTA, N., The bioavailability of chemicals in soil for earthworms, Ecotoxicol. Environ. Saf., 57, 2004, 39-47.

https://doi.org/10.1016/j.ecoenv.2003.08.014

66. PEIJNENBURG, W., POSTHUMA, L., EIJSACKERS, H., ALLEN, H., A conceptual framework for implementation of bioavailability of metals for environmental management purposes, Ecotoxicol. Environ. Saf., 37, 1997, 163-172. https://doi.org/10.1006/eesa.1997.1539

67. HARMSEN, J., Measuring bioavailability: from a scientific approach to standard methods, $J$. Environ. Qual., 36, 2007, 1420-1428.

68. ISO/DIS, (2006), Soil quality. Guidance for the selection and application of methods for the assessment of bioavailability of contaminants in soil and soil materials, ISO/DIS 17402:2006, International Organization for Standardization, Geneva, Switzerland.

69. ANYANWU, B.O., EZEJIOFOR, A.N., IGWEZE, Z.N., ORISAKWE, O.E., Heavy metal mixture exposure and effects in developing nations: an update, Toxics, 6, 2018, 65.

https://doi.org/10.3390/toxics6040065

70. MALEKI, M., GHORBANPOUR, M., KARIMAN, K., Physiological and antioxidative responses of medicinal plants exposed to heavy metals stress, Plant Gene, 11, 2017, 247-254.

https://doi.org/10.1016/j.plgene.2017.04.006

71. LAJAYER, B.A., GHORBANPOUR, M., NIKABADI, C., Heavy metals in contaminated environment: Destiny of secondary metabolite biosynthetis, oxidative status and phytoextraction in medicinal plants, Ecotoxicol. Environ. Saf., 145, 2017, 377-390.

http://doi.org/10.1016/j.ecoenv.2017.07.035

72. NOUAIRI, I., BEN, A.W., BEN, Y.N., BEN, M.D.D., GHORBAL, M.H., ZARROUK, M., Antioxidant defense system in leaves of Indian mustard (Brassica juncea) and rape (Brassica napus) under cadmium stress, Acta Physiol. Plant, 31, 2009, 237-247, https://doi.org/10.1007/s11738-008$\underline{0224-9}$

73. OUESLATI, S., KSOURI, R., PICHETTE, A., LAVOIE, S., GIRARD-LALANCETTE, K., MSHVILDADZE, V., ABDELLY, C., LEGAULT, J., A new flavonol glycoside from the medicinal halophyte Suaeda fruticosa, Nat. Prod. Res, 28, 2014, 960-966.

http://doi.org/10.1080/14786419.2014.900771

74. GALAL, T.M., SHEHATA, H.S., Bioaccumulation and translocation of heavy metals by Plantago major L. grown in contaminated soils under the effect of traffic pollution, Ecol. Indic., 48, 2015, 244251. https://doi.org/10.1016/j.ecolind.2014.08.013

75. ANGElOVA, V.R., , GREKOV, D.F., KISYOV, V.K., IVANOV, K.I., Potential of lavender (Lavandula vera L.) for phytoremediation of soils contaminated with heavy metals, Int. J. Biol., Food Vet. Agric. Eng., 9, 2015, 465-472.

76. LAJAYER, B.A., NAJAFI, N., MOGHISEH, E., MOSAFERI,; HADIAN, J., Micronutrient and heavy metal concentrations in basil plant cultivated on irradiated and non irradiated sewage sludgetreated soil and evaluation of human health risk, Regul. Toxicol. Pharmacol., 104, 2019, 141-150.

77. FATTAHI, B., ARZANIA, K., SOURIA, M.K., BARZEGAR, M., Effects of cadmium and lead on seed germination, morphological traits, and essential oil composition of sweet basil (Ocimum basilicum L.), Ind. Crops. Prod., 138, 2019, 111584. https://doi.org/10.1016/j.indcrop.2019.111584. 
78. ANJU, P., VINEETA, P., PATRA, D.D., Metal absorption properties of Mentha spicata grown under tannery sludge amended soil-its effect on antioxidant system and oil quality, Chemosphere, 147, 2016, 67-73. https://doi.org/10.1016/j.chemosphere.2015.12.097

79. SUNAYANA, G., SUCHISMITA, D., Copper phytoremediation potential of Calandula officinalis L. and the role of antioxidant enzymes in metal tolerance, Ecotoxicol. Environ. Saf., 126, 2016, 211218. http://doi.org/10.1016/j.ecoenv.2015.12.030

80. ZHELJAZKOV, V.D., CRAKER, L.E., XING, B., NIELSEN, N.E., WILCOX, A., Aromatic plant production on metal contaminated soils, Sci. Total Environ, 395, 2008, 51-62.

https://doi.org/10.1016/j.scitotenv.2008.01.041

81. KOVÁC̆IK, J., TOMKO, J., BAČKOR, M., REPČÁK, M., Matricariachamomilla is not a hyperaccumulator, but tolerant to cadmium stress, Plant Growth Regul., 50, 2006, 239-247. https://doi.org/10.1007/s10725-006-9141-3

82. GAJALAKSHMI, S., ISWARYA, V., ASHWINI, R., DIVYA, G., MYTHILI, S., SATHIAVELU, A., Evaluation of heavy metals in medicinal plants growing in Vellore District, Eur. J. Exp. Biol., 2, 2012, 1457-1461.

83. REZA, M., ALIASGHAR, R., ALIREZA, S., Heavy metals detoxification: A review of herbal compounds for chelation therapy in heavy metals toxicity, J. Herbmed. Pharmacol., 8, 2019, 69-77. http://doi.org/10.15171/jhp.2019.12

84. WANG, Z., WANG, H., WANG, H., LI, Q., LI, Y., Heavy metal pollution and potential health isks of commercially available Chinese herbal medicines, Sci. Total Environ., 653, 2017, 748-757. http://doi.org/10.1016/j.scitotenv.2018.10.388

85. ZHANG, J., WANG, W.K., GENG, Y.N., WANG, Z.F., CAO, S.M., Effect of $\mathrm{Cd}^{2+}$ stress on seed germination characteristics of ryegrass, Indian mustard and grain amaranth, Environ Eng. Manag. J., 18, 2019, 1875-1884.

86. NAFIU, M.O., HAMID, A.A., MURITALA, H.F., ADEYEMI, S.B., Preparation, Standardization, and Quality Control of Medicinal Plants in Africa, In: Medicinal Spices and Vegetables from Africa, Kuete V. (Ed.). Elsevier, 2017, 171-204. https://doi.org/10.1016/B978-0-12809286-6.00007-8.

87. NICA BADEA, D., Determination of potentially toxic heavy metals $(\mathrm{Pb}, \mathrm{Hg}, \mathrm{Cd})$ in popular medicinal herbs in the coal power plant area, Rev. Chim., 66, 2015, 1132-1136.

88. DIACONU, D., DIACONU, R., NAVROTESCU, T., Estimation of heavy metals in medicinal plants and their infusions, Ovidius Univ. Ann. Chem., 23, 2012, 115-120.

http://doi.org/10.2478/v10310-012-0019-0

89. MUNTEAN, N., MUNTEAN, E., CRETA, C., DUDA, M., Heavy metals in some commercial herbal teas, ProEnvironment, 6, 2013, 591-594. http://journals.usamvcluj.ro/index.php/promediu

90. GHAZALA, Y., FIZZA, I., MUNIBA, I., VANIA, M., Monitoring and risk assessment due to presence of heavy metals and pesticides in tea samples, Food Sci. Technol., 38, 2018, 625-628. https://doi.org/10.1590/fst.07417

91. MAHMOUD, M.G., MONA, A.K., MOHAMED, R., SHOROUK, M.M., GIHAN, H., Assessment of the potential health risk of heavy metal exposure from the consumption of herbal, black and green tea, Biomed. J. Sci. Tech. Res., 16, 2019, 11810-11817.

http://doi.org/10.26717/BJSTR.2019.16.002806

92. BRIMA, E.I., Levels of Essential Elements in Different Medicinal Plants Determined by Using Inductively Coupled Plasma Mass Spectrometry. J. Anal. Methods Chem., 1-6, 2018. 10.1155/2018/7264892.

93. FISCHER, A., BRODZIAK-DOPIERALA, B., LOSKA, K., STOJKO, J., The assessment of toxic metals in plants used in cosmetics and cosmetology, Int. J. Environ. Res. Public Health, 14, 2017. http://doi.org/10.3390/ijerph14101280 
94. WELDON, M.M.; SMOLINSKI, M.S., MAROUFI, A., HASTY, B.W., GILLISS, D.L., BOULANGER, L.L., BALLUZ, L.S. DUTTON, R.J., Mercury poisoning associated with a Mexican beauty cream, West. J. Med., 173, 2000, 15-19. http://doi.org/10.1136/ewjm.173.1.15

95. ZHENG, S., WANG, Q., YUANY SUN, W, Human health risk assessment of heavy metals in soil and food crops in the Pearl River Delta urban agglomeration of China, Food Chem., 316, (2020). https://doi.org/10.1016/j.foodchem.2020.126213.

96.KOHZADI, S., SHAHMORADI, B., GHADERI, E., LOQMANI, H., MALEKI, A., Concentration, source, and potential human health risk of heavy metals in the commonly consumed medicinal plants, Biol. Trace Elem. Res., 2018. https://doi.org/10.1007/s12011-018-1357-3

97.OKATCH, H., NGWENYA, B., RALETAMO, K.M., ANDRAE-MAROBELA, K., Determination of potentially toxic heavy metals in traditionally used medicinal plants for HIV/AIDS opportunistic infections in Ngamiland District in Northern Botswana, Anal. Chim. Acta, 730, 2012, 42-48, https://doi.org/10.1016/j.aca.2011.11.067

98. ZHAO, Q., WANG, Y., CAO, Y., CHEN, A., REN, M., GE,Y., YU, Z., WAN, S., HU, A., BO, Q., Potential health risks of heavy metals in cultivated topsoil and grain, including correlations with human primary liver, lung and gastric cancer, in Anhui province, Eastern China, Sci. Total Environ., 470, 2014, 340-347. http://doi.org/10.1016/j.scitotenv.2013.09.086

99. WHO, 2003, WHO guidelines on good agricultural and field collection practices (GACP) for medicinal plants, WHO, Geneva.

100. FAO, 2005, The state of food insecurity in the World: Eradicating world hunger- key to achieving the Millennium Development Goals, FAO, Rome.

101. USEPA, 2011, Exposure Factors Handbook: 2011 Edition, Office of Research and Development, U.S. Environmental Protection Agency, Washington DC, On line at:

https://cfpub.epa.gov/ncea/risk/recordisplay.cfm?deid=236252

102.ABBASI, A.M., IQBAL, J., KHAN, M.A., SHAH, M.K., Health risk assessment and multivariate apportionment of trace metals in wild leafy vegetables from Lesser Himalayas, Pakistan, Ecotoxicol. Environ. Saf., 92, 2013, 237-244.

https://doi.org/10.1016/j.ecoenv.2013.02.011

103. LI, N.Y., FU, Q.L., ZHUANG, P., GUO, B., ZOU, B., LI, Z.A., Effect of fertilizers on Cd uptake of Amaranth hypochondriacus, a high biomass, fast growing and easily cultivated $\mathrm{Cd}$ hyperaccumulator", Int. J. Phytorem., 14, 2012, 162-173.

http://doi/10.1080/15226514.2011.587479

$\overline{\text { Manuscript received: } 3.06 .2020}$ 